\title{
Field Test of "U-Champ" Biosurfactant in Oil Spill Bioremediation
}

\author{
Harry Budiharjo Sulistyarso, Joko Pamungkas, Sri Rahayu G, Indah Widiyaningsih, Kevin Yudha \\ Perwira
}

\begin{abstract}
One of the serious environmental problems of the oil and gas industry is handling oil spills. Oil spills can be managed by using bioremediation in the form of biosurfactants. In this research, biosurfactants called U-Champ were used which can impact in remediation of oil spills. The research conducted was testing the effectiveness of biosurfactants on Cepu Field contaminated soil in reducing TPH and heavy metals. The method is done by stirring the contaminated soil with various concentrations of biosurfactant product in an artificial tank. Based on the test results, a decline in TPH and TCLP along with the increase in U-Champ biosurfactant concentration was used. The addition of 6 Liters of biosurfactant gave the most significant reduction. Some of the heavy metals in the soil decrease, but some also have increased. As an example, it can be seen in $\mathrm{Ba}$ metal, the addition of U-Champ biosurfactant as much as $1.5 \mathrm{~L}$ $(0.3 \% v / v)$ resulted in a decrease in TCLP of $11.085 \%$. The qualitative result is evidenced by the growth of various plants in each artificial tank.
\end{abstract}

Keywords: Biosurfactant, Bioremediation, Oil Spills, U-Champ

\section{INTRODUCTION}

$\mathrm{P}_{\text {etroleum has the role as one of the most important }}$ sources of raw material and energy for industry nowadays. Dependence on petroleum as an energy source such as fuel has influenced the development of the economic sector. Although the petroleum industry is very beneficial to society, this industry also produces a lot of hazardous waste. Furthermore, one of the liquid waste such as oil spills caused environmental problems during the exploration, transportation, and refining processes (Silva et al., 2014). The characteristics of crude oil in KW-58 well Cepu, Blora Regency, Central Java Province are that it has a high viscosity and low density. According to the author's data, the density of Wonocolo crude oil is $0.90323 \mathrm{~g} / \mathrm{mL}$ at a temperature of $60^{\circ} \mathrm{C}$ and the viscosity of the oil is $8.23 \mathrm{cp}$ at a temperature of $35.3^{\circ} \mathrm{C}$.

Manuscript received on August 31, 2021.

Revised Manuscript received on September 07, 2021.

Manuscript published on September 30, 2021.

*Correspondence Author

Harry Budiharjo Sulistyarso*, Associate Professor, Department of Petroleum Engineering, UPN

"Veteran",Yogyakarta.

Joko Pamungkas, Lecturer, Department of Petroleum Engineering UPN "Veteran" Yogyakarta.

Sri Rahayu Gusmarwani, Lecturer, Department of Chemical Engineering, STTNAS.

Indah Widyaningsih, Lecturer, Department of Petroleum Engineering UPN "Veteran" Yogyakarta.

Kevin Yudha Perwira. Department of Environmental Engineering, UPN "Veteran" Yogyakarta.

(C) The Authors. Published by Blue Eyes Intelligence Engineering and Sciences Publication (BEIESP). This is an open access article under the CC BY-NC-ND license (http://creativecommons.org/licenses/by-nc-nd/4.0/)
The oil is only found on the soil surface due to poor infiltration power. This can be due to high oil viscosity and high soil porosity. Previous research (Bada et al., 2012) explained the dangers of soil contamination by oil spills on abiotic and biotic components. TPH levels in the soil can affect soil fertility and affect vegetation in the long term. This statement fructifies the requirement for oilcontaminated remediation in the soil contaminated to remove the oil content. U-champ is a biosurfactant that can reduce TPH levels from polluted soil. U-champ can work as a soil washer which will dissolve TPH in polluted soil and carried away as leachate. U-champ is extracted from microorganisms that live in the digestive system of cows. Based on the previous study (Sulistyarso et al., 2019), Uchamp is proved to be effective to reduce TPH and heavy metals in the soil. This study aims to test a new formula in the use of U-champ and test its bioavailability by evaluating the density parameters of the growing weeds.

\section{LITERATURE REVIEW}

The environment itself can degrade the pollutants that enter it, but often the load pollution in the environment is greater than the speed of the natural pollutant degradation process. As a result, pollutants will accumulate so that human intervention with existing technology is needed to overcome this pollution. Bioremediation becomes one of the technologies to restore contaminated earth soil petroleum hydrocarbons. In terms of cost and environmental sustainability, bioremediation is cheaper and environmentally friendly compared to the other environmental restoration methods (Kusumawati et al., 2015). The concept of bioremediation is to use living microorganisms to decrease or remove environmental hazards due to the accumulation of toxic material such as toxic wastes. Bioremediation gives an option to offers possibility to eliminate or create a variety of harmless contaminants using natural biological activities. Furthermore, to increase the effectiveness in bioremediation, it can also be done by conjunct it with various physical and chemical technologies to give a better result. Bioremediation functions on biodegradation, which functioning by complete demineralization of complex organic contaminants into a simpler compound as $\mathrm{CO}_{2}, \mathrm{H}_{2} \mathrm{O}$, inorganic compounds, and cell proteins that are harmless for the environment (Speight \& Arjoon, 2012). This makes bioremediation the best choice for dealing with organic waste such as petroleum waste (Balba et al., 1998). Surfactants are a product of microorganisms that have an amphiphilic molecule.

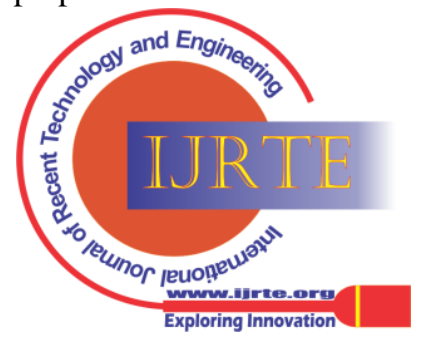




\section{Field Test of "U-Champ" Biosurfactant in Oil Spill Bioremediation}

It means that surfactants possess both hydrophilic and lipophilic properties that are composed of a hydrophilic head and lipophilic tail. It has the ability to separate oily materials from certain media by attracting oily and non-oily materials with its dual properties (amphiphilic). (Urum \& Pekdemir, 2004). This characteristic makes biosurfactant is widely used for cleaning substances like detergent and soap. Biosurfactants are surfactant substances that are synthesized by living organisms and have the properties like an active surfactant, but generally non-toxic, and biodegradable (Banat et al., 2000). Biosurfactants are important biotechnology inventions with plentiful functions in many industries. Some of the interesting properties of biosurfactants including changing the active surface such as reducing the IFT (interface tension); moisturizes and penetrates the media; spread; hydrophobic and hydrophilic; a catalyst for microbial development; absorb metal; antimicrobial. Some of the advantages of biosurfactants compared to other synthetic chemical products are biodegradable; have a low level of toxicity; biocompatible and digestible; can be obtained from cheap materials; and are economical (Kosaric, 2001).

Soil washing is one of the ex-situ techniques in bioremediation that use physical and chemical procedures to separate metals and other contaminants from soils (Dermont et al., 2008). Soil washing is a potential technology for clearing contaminated soil. There has been much research to investigate the effectiveness of soil washing to remove hydrocarbon from contaminated soil and the cause of leaching on the polycyclic aromatic hydrocarbon's biodegradability (Haapea \& Tuhkanen, 2006).

\section{MATERIALS AND METHOD}

The soil used is the soil from the location of petroleum exploitation in Cepu, Blora Regency, Central Java Province. The soil at that location is of the grumusol type with a limestone source rock and has a dusty clayey loam texture. At the preparation stage, the soil is treated with crude oil which is taken from the KW-58 well. The sample soil has a volume of $450 \mathrm{~L}$ with the addition of $50 \mathrm{~L}$ of crude oil. The process of mixing and remediation of this soil is carried out using the ex-situ method which is carried out by making four control tanks. The soil that has been given crude oil is washed with $50 \mathrm{~L}$ of water and mixed for 30 minutes. After being mixed, U-Champ biosurfactant was put into each bath with different volumes: $0 \mathrm{~L}$ in $1^{\text {st }}$ Tank, $1.5 \mathrm{~L}$ in $2^{\text {nd }}$ Tank, $2.25 \mathrm{~L}$ in $3^{\text {rd }}$ Tank, and $6 \mathrm{~L}$ in $4^{\text {th }}$ Tank, and then mixed until it became homogeneous. The oil and liquid phases (leachate) will separate and be carried together to the leachate channel. The remaining soil will be allowed to dry out for testing with parameters TPH, pH, and TCLP.

Table 1. U-Champ Dose each tank

\begin{tabular}{lccccc}
\hline & & $1^{\text {st }}$ Tank & $2^{\text {nd }}$ Tank & $3^{\text {rd }}$ Tank & $4^{\text {th }}$ Tank \\
\hline $\begin{array}{l}\text { U-Champ } \\
(\mathrm{L})\end{array}$ & Dose & 0 & 1.5 & 2.25 & 6
\end{tabular}

The second test aims to check the bioavailability of the treated soil. After one month of testing, the soil bioindicator was observed in the form of weeds. The growth of weeds with high density indicates that the processed soil has good bioavailability so that it can be overgrown with vegetation.

\section{RESULT AND DISCUSION}

The test used for TPH detection is EPA 9071 B Mod, while TCLP testing uses XRF (X-Ray Fluorescence). There was a decrease in TPH and TCLP along with the increase in U-Champ biosurfactant used. The regression line of the decline in TPH can be seen in Figure 1.

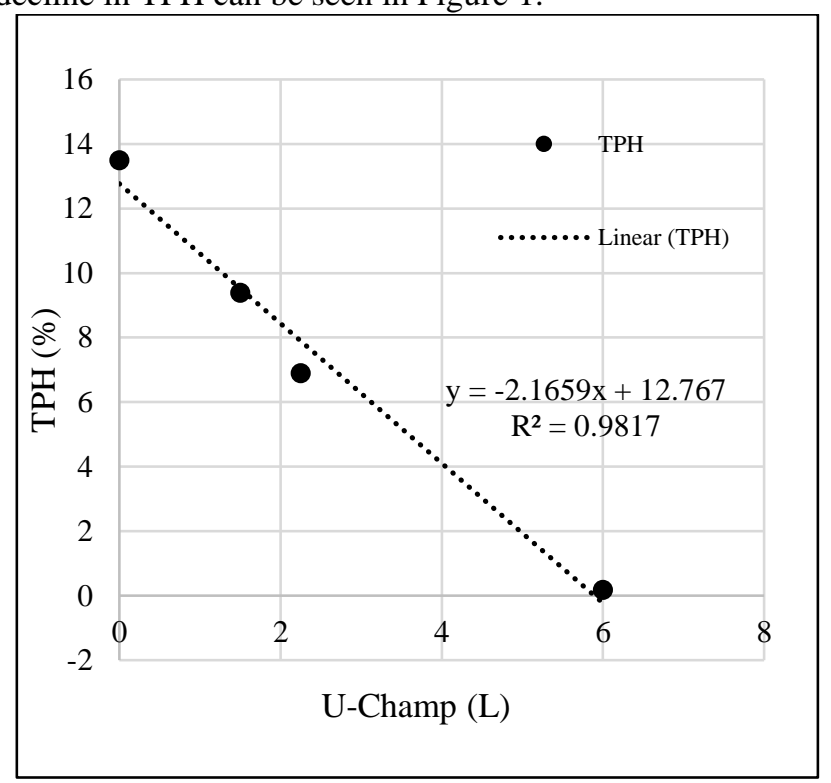

Figure 1. TPH (\%) Vs U-Champ Concentration

As can be seen in the graph, the addition of U-Champ biosurfactant affected the decrease in TPH. This indicates that the soil washing method using U-Champ biosurfactant can dissolve hydrocarbons in polluted soil. Based on the graph, the addition of $6 \mathrm{~L} \mathrm{U}$-Champ in the $4^{\text {th }}$ tank gives the best decreasing value of TPH to $0.18 \%$ compared to the $1^{\text {st }}$ tank with the addition of $0 \mathrm{~L}$ U-Champ. The hydrocarbon solution will be transported and carried as leachate which must then be processed. The equation obtained has an R2 value of 0.9817 which indicates that the trendline data on the TPH decline graph is good. So that it can be calculated the efficiency value of the biosurfactant must be used following the applicable regulations. The formula $\mathrm{y}=$ $2.1659 x+12,767$ is obtained with the value of $y$ as the percent of TPH and $\mathrm{x}$ as the addition of the given U-Champ biosurfactant. The decrease in compound concentration did not only occur in the TPH parameter, but also the heavy metal parameter. Can be seen in Table 2 is a data table for each parameter tested in each tank. The higher the addition of U-Champ biosurfactant, the higher the solubility level of the metal as well. As an example, it can be seen in Ba metal, the addition of U-Champ biosurfactant as much as $1.5 \mathrm{~L}$ $(0.3 \% \mathrm{v} / \mathrm{v})$ resulted in a decrease in TCLP of $11.085 \%$ Another example can be seen in the $\mathrm{pH}$ of each sample, the higher the addition of U-Champ the more neutral the $\mathrm{pH}$ will be. It can be done because the base element in the contaminant has already been washed away with the UChamp. The effectiveness of biosurfactants U-Champ in reducing the interfacial tension between oil and water and the ability to reduce viscosity can separate oil from soil particulates so that the lifted oil will then float to the surface (Sianipar \& Kardena, 2011).

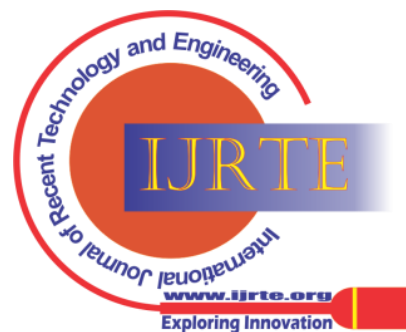


Table 2. U-Champ Application in Bioremediation.

\begin{tabular}{lcccc} 
Parameter & $1^{\text {st }}$ Tank & $2^{\text {nd }}$ Tank & $3^{\text {rd }}$ Tank & $4^{\text {th }}$ Tank \\
\hline $\mathrm{pH}$ & 9.21 & 9.14 & 8.78 & 8.34 \\
\hline $\mathrm{TPH}$ & 13.49 & 9.39 & 6.89 & 0.18 \\
\hline $\mathrm{Pb}$ & 6.45 & 4.75 & 3.74 & 1.87 \\
\hline $\mathrm{Ba}$ & 232.2 & 206.46 & 174.78 & 132.6 \\
\hline $\mathrm{Cr}$ & 12.9 & 8.3 & 6.21 & 3.33 \\
\hline $\mathrm{Cu}$ & 19.98 & 15.56 & 9.2 & 7.8 \\
\hline $\mathrm{Hg}$ & 0.32 & 0.21 & 0.18 & 0.07 \\
\hline $\mathrm{Se}$ & 1.11 & 0.96 & 0.89 & 0.7 \\
\hline $\mathrm{Zn}$ & 64.5 & 50.2 & 42.79 & 23.31
\end{tabular}

Bioindicators are needed in this test to monitor levels of biological toxicity. Figure 2 is the appearance of the treated soil after one month. $4^{\text {th }}$ tank has the highest vegetation density with the highest U-champ value. This proves that the bioavailability in the $4^{\text {th }}$ tank has the highest value. It can be seen in the figure that the level of U-champ is directly proportional to the level of bioavailability of the treated soil. This can happen because the contaminants in the processed soil have been washed by the U-champ so the oily contaminant is being transported away. With the absence of oil spills, the bioavailability level in the soil sample will increase and allow vegetation to grow properly.
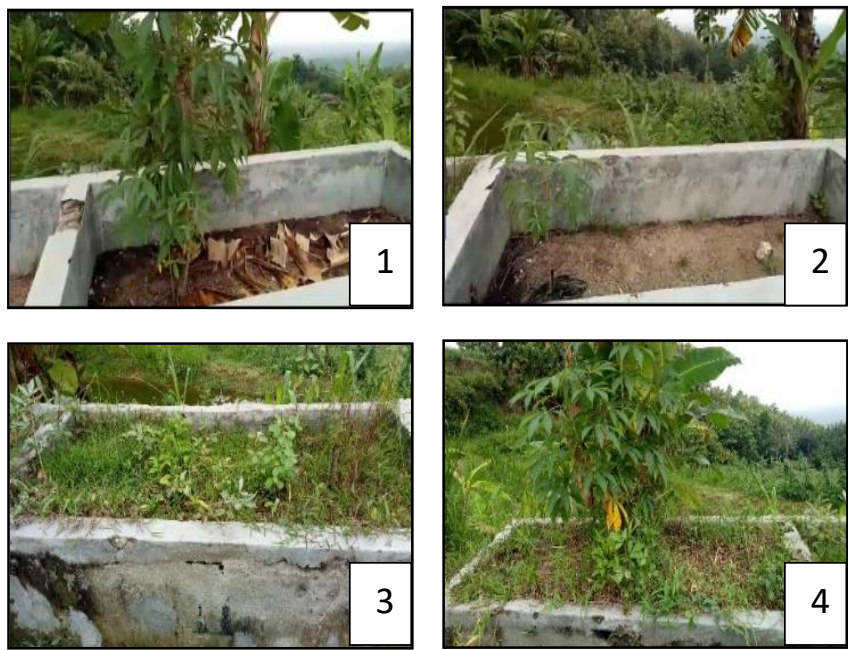

Figure 2. Comparation of bioavailability each tank based on weeds growth as a bioindicator (1) $1^{\text {st }}$ Tank (2) $2^{\text {nd }}$ Tank (3) $3^{\text {rd }}$ Tank (4) $4^{\text {th }}$ Tank

\section{CONCLUSION}

U-Champ biosurfactant has been shown to be effective in lowering TPH and heavy metals. The addition of $6 \mathrm{~L}$ of biosurfactant in the $4^{\text {th }}$ tank gave the most significant reduction. The amount of U-Champ biosurfactant required depends on the quality standard of the desired contamination parameter, which can be calculated from the value of the concentration reduction equation for parameters such as TPH so that the efficient volume of U-Champ biosurfactant can be determined. U-champ has also been shown to increase bioavailability by washing polluted soil. This happens because the levels of toxic waste in the soil have been transported with leachate.

\section{ACKNOWLEDGEMENT}

This paper is made as the result of our research in Penelitian Terapan Unggulan Perguruan Tinggi (PTUPT) RISTEKDIKTI. We thank RISTEKDIKTI for the research fully funding. We thank to PT PERTAMINA EP Field Cepu and EOR LABORATORY of Petroleum Engineering Department, UPN "Veteran" Yogyakarta for the support that has been given in this research.

\section{REFERENCES}

1. Bada, B. S., Olarinre, T. A., \& Saheed Bada, B. (2012) Characteristics of Soils and Heavy Metal Content of Vegetation in Oil Spill Impacted Land in Nigeria PART I: Heavy Metals CHARACTERISTICS OF SOILS AND HEAVY METAL CONTENT OF VEGETATION IN OIL SPILL IMPACTED LAND IN NIGERIA. Tosin Akinola, 17.

2. Balba, M. T., Al-Awadhi, N., \& Al-Daher, R. (1998) Bioremediation of oil-contaminated soil: microbiological methods for feasibility assessment and field evaluation. Journal of Microbiological Methods, 32(2), 155-164.

3. Banat, I. M., Makkar, R. S., \& Cameotra, S. S. (2000). Potential commercial applications of microbial surfactants. Applied Microbiology and Biotechnology, 53(5), 495-508.

4. Budiharjo, H., Pamungkas, J., G, S. R., \& Perwira, K. Y. (2019). Uji Laboratorium Efektivitas Biosurfaktan " U - Champ " dalam Bioremediasi Oil Spill. Jurnal Mineral , Energi, Dan Lingkungan, 3(2), 101-106.

5. Dermont, G., Bergeron, M., Mercier, G., \& Richer-Laflèche, M. (2008). Soil washing for metal removal: A review of physical/chemical technologies and field applications. Journal of Hazardous Materials, 152(1), 1-31.

6. Haapea, P., \& Tuhkanen, T. (2006). Integrated treatment of PAH contaminated soil by soil washing, ozonation and biological treatment. Journal of Hazardous Materials, 136(2), 244-250.

7. Kosaric, N. (2001). Biosurfactants and Their Application for Soil Bioremediation. Food Technol. Biotechnol, 39(4), 295304.

8. Kusumawati, E., Kholiq, M. A., Mulawarman, U., Pertanian, F. T., Malang, U. B., Lingkungan, B. T., \& Tengah, J. (2015). Aplikasi Bakteri Untuk Bioremediasi Lahan Tercemar Minyak Bumi ( Crude Oil ) Menggunakan. 03(April), 1-44.

9. Sianipar, M., \& Kardena, E. (2011). The Effects of Biosurfactant As Oily Sludge Pretreatment in Decreasing Tph Through Oil Recovery At Slurry Phase Bioremediation Technique. Jurnal Teknik Lingkungan, 17(1), 23-34.

10. Silva, R. de C. F. S., Almeida, D. G., Rufino, R. D., Luna, J. M., Santos, V. A., \& Sarubbo, L. A. (2014). Applications of biosurfactants in the petroleum industry and the remediation of oil spills. International Journal of Molecular Sciences, 15(7), 1252312542.

11. Speight, J. G., \& Arjoon, K. K. (2012). Bioremediation of Petroleum and Petroleum Products. In Bioremediation of Petroleum and Petroleum Products.

12. Urum, K., \& Pekdemir, T. (2004). Evaluation of biosurfactants for crude oil contaminated soil washing. Chemosphere, 57(9), 1139 1150 .

\section{AUTHORS PROFILE}

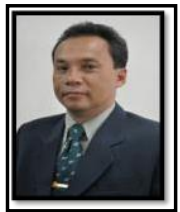

Harry Budiharjo Sulistyarso. is Assosiate Professor in Petroleum Engineering Department UPN "Veteran",Yogyakarta. At the moment, he is active as lecturer and researcher in Enhanced Oil Recovery. Received his doctorate degree (S3) in Petroleum Engineering ITB in 2007. He obtained Bachelor degree (S1) in Petroleum Engineering from UPN "Veteran" Yogyakarta in 1990, and Master's degree (S2) in Petroleum Engineering from ITB in 1997. Professional Organization joined: The Institution of Engineers Indonesia (PII), Society of Indonesian Petroleum Engineers (IATMI), Indonesian Petroleum Association (IPA) and Society of Petroleum Engineers (SPE).

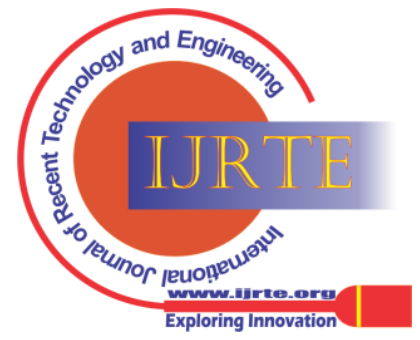


Field Test of "U-Champ" Biosurfactant in Oil Spill Bioremediation

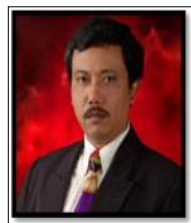

Joko Pamungkas. Received his B.E. from UPN

"Veteran" Yogyakarta. Received his M.Eng. from Bandung Institute of Technology (ITB) Mr. Joko Pamungkas become lecturer in Petroleum Engineering Department UPN "Veteran" Yogyakarta since 1993 Mr. Joko Pamungkas also become a consultant in petroleum industry for more than 25 years. Experienced in oil and gas plan of development (POD). Professional Organization joined: The Institution of Engineers Indonesia (PII), Society of Indonesian Petroleum Engineers (IATMI), Indonesian Geothermal Association (INAGA), and Indonesian Petroleum Association (IPA).

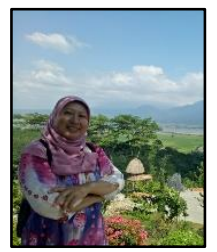

Sri Rahayu Gusmarwani. Born in Pati on July 11, 1971. Graduated with a Bachelor's degree in Chemical Engineering, UPN "Veteran" Yogyakarta in 1995. Worked as Head of Biscuit Processing Unit at Jangkar Mas Nusantara Gresik, a food company in Driyorejo Gresik, East Java, until 1996. 1996-1997 became a practicum assistant in the Basic Chemistry laboratory of UPN "Veteran" Yogyakarta. His first experience was being a lecturer at the Chemical Engineering Department of STTNAS (now ITNY) in 1997-2012. He studied Chemical Engineering Masters at UGM in 1998-2002. Moved home base at AKPRIND Institute of Science \& Technology Yogyakarta from 2013 until now.

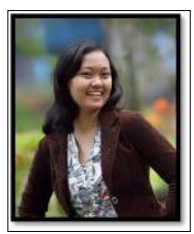

Indah Widyaningsih. Received her B.E. from UPN "Veteran" Yogyakarta. Received her M.Eng. from Bandung Institute of Technology. Worked at JOB Pertamina-Medco E\&P Tomori for 4.5 years. Joined research at Ogrindo, ITB for 6 years and become a lecturer in Petroleum Engineering Department UPN "Veteran" Yogyakarta since 2013. Professional Organization joined: Society of Indonesian Petroleum Engineers (IATMI).

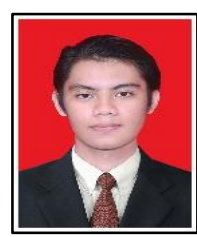

Kevin Yudha Perwira. Graduated Bachelor Engineering in Enviromental Engineering Department, UPN "Veteran" Yogyakarta in 2021

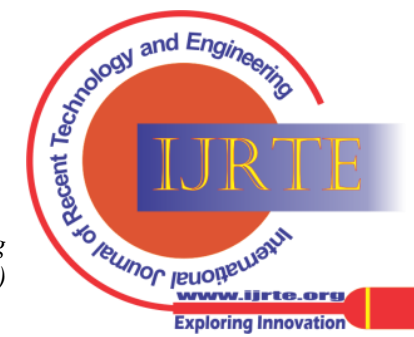

